\title{
Terhességi ritmuszavarok modern terápiás megközelítései
}

\author{
Riba Ádám dr. ${ }^{1}$ - Németh Barnabás dr. ${ }^{1}$ - Árvai Ferenc dr. ${ }^{1,2}$ \\ Lupkovics Géza dr. ${ }^{1}$. Tahin Tamás dr. ${ }^{1}$
}

${ }^{1}$ Zala Megyei Szent Rafael Kórház, Kardiológia Osztály, Zalaegerszeg

${ }^{2}$ Markusovszky Egyetemi Oktatókórház, Szombathely

\begin{abstract}
A ritmuszavarok előfordulása gyakoribb a terhes nők esetén, mint a nem várandósok körében. A legtöbb esetben terápiás beavatkozás nélkül is kihordható a magzat. Hemodinamikai instabilitás és magzatkárosodáshoz vezető fetalis hypoperfusio jöhet létre, amennyiben tartós, magas kamrai frekvenciával járó epizódok jelentkeznek. Ezekben az esetekben a ritmuszavar megszüntetése indokolttá válhat. Az antiarrhythmiás gyógyszerek korlátozottan és nagy körültekintéssel alkalmazhatók a gyermeket várók körében, így a katéterablatio jelenthet biztonságos és használható alternatívát. Ezen beavatkozásokat hagyományosan röntgensugár segítségével végzik, ez azonban az ionizáló sugárzásnak a magzati fejlődésre gyakorolt hatása miatt magas rizikót jelentene. Több éve elérhető a szív-elektrofiziológiában az ún. zéró fluoroszkópiás ablatio, mely a pitvarfibrilláció kezelésében és más ritmuszavarok esetében egyaránt alkalmazható. A terheseknél alkalmazott eljárást két eseten keresztül mutatjuk be. A röntgensugár használatát, a jelen cikkben bemutatott beavatkozások esetén is, sikerült teljesen kiküszöbölnünk. Az első, 23 hetes gravid páciensnél recidív paroxysmalis supraventricularis tachycardia miatt végeztünk elektrofiziológiai vizsgálatot. E vizsgálat során atrioventricularis nodalis reentry tachycardiát igazoltunk és abláltunk sikerrel. Második esetbemutatásunkban egy anteroseptalis járulékos köteg katéterablatiós megoldását mutatjuk be. A terhesség során jelentkező, az anyára és/ vagy magzatára veszélyt jelentő ritmuszavar esetén a háromdimenziós térképező rendszer (szükség esetén intracardialis ultrahangvizsgálattal kiegészítve) biztonságos és hatásos alternatívát jelent, olyan esetekben, ha röntgensugár nem használható.
\end{abstract}

Orv Hetil. 2021; 162(41): 1643-1651.

Kulcsszavak: terhesség, ritmuszavarok kezelése, katéterablatio, röntgensugár nélkül

\section{Modern therapeutic approaches of cardiac arrhythmias in pregnancy}

Arrhythmias are more common in pregnant women than in others. In most cases, the fetus can be delivered without therapeutic intervention. Hemodynamic instability and fetal hypoperfusion leading to fetal harm may occur if persistent episodes of high ventricular rate occur. In these cases, resolution of the arrhythmia may be advised. Antiarrhythmic drugs can be used with limitations and great caution in those expecting a child, so catheter ablation may be a safe and usable alternative. These interventions are traditionally performed using X-ray, however, due to the effect of ionizing radiation on fetal development, this would pose a high risk. Zero-fluoroscopic ablation has been available for several years in cardiac electrophysiology, which can be used both in the treatment of atrial fibrillation and in other arrhythmias. The procedure which we used in pregnant women is presented in two cases. We also managed to completely eliminate the use of X-ray during the interventions presented in this article. In the first case, a 23-weekold gravid patient underwent electrophysiological examination for recurrent paroxysmal supraventricular tachycardia. In the electrophysiological study, atrioventricular nodal reentry tachycardia was confirmed and successfully ablated. In our second case study, we present a catheter ablation for anteroseptal accessory pathway. Three-dimensional mapping system (supplemented with intracardiac ultrasound, if necessary), in the case of significant arrhythmia, is a safe and effective alternative where X-rays, which poses a risk to the mother and/or the fetus, cannot be used during pregnancy.

Keywords: pregnancy, treatment of arrhythmias, catheter ablation, zero-fluoroscopy

Riba Á, Németh B, Árvai F, Lupkovics G, Tahin T. [Modern therapeutic approaches of cardiac arrhythmias in pregnancy]. Orv Hetil. 2021; 162(41): 1643-1651.

(Beérkezett: 2021. január 31.; elfogadva: 2021. március 9.) 


\section{Rövidítések}

AHA $=($ American Heart Association $)$ Amerikai Szívgyógyász Szövetség; ALARA = (as low as reasonably achievable $)$ a lehetó legalacsonyabb, de még az adott terápiás vagy diagnosztikai cél eléréséhez szükséges (dózis); AV = atrioventricularis; AVNRT = AV nodalis reentry tachycardia; $\mathrm{ECHO}=$ echokardiográfia; $\mathrm{EKG}=$ elektrokardiogram; ESC $=$ (European Society of Cardiology) Európai Kardiológus Társaság; FDA = (U.S. Food and Drug Administration) az Amerikai Egyesült Államok Élelmiszer-biztonsági és Gyógyszerészeti Hivatala; ICE = (intracardiac ECHO) intracardialis ultrahangvizsgálat; IST = (inappropriate sinus tachycardia) aránytalan sinustachycardia; $\mathrm{LMWH}=$ (low-molecular-weight heparin) alacsony molekulatömegü heparin; NOAC $=($ novel oral anticoagulants $)$ új típusú oralis antikoagulánsok; PJRT = paroxysmalis junkcionális reciprok tachycardia; PSVT = paroxysmalis supraventricularis tachycardia; $\mathrm{QTc}=($ corrected QT $)$ korrigált QT; SVT $=$ supraventricularis tachycardia; VT = ventricularis tachycardia; WPW = Wolf-Parkinson-White-szindróma

A terhesség során a magzatot számos behatás éri amellett, hogy a terhesség maga is fokozott megterhelést jelent a nő számára. A káros, külső hatások csökkentése a méhen belüli fejlődés szempontjából elengedhetetlen fontosságú. A megváltozott keringési viszonyok, a hormonális és pszichés változások, a testsúly megnövekedése a szív- és keringési rendszert is nagymértékben igénybe veszi. Ezek a változások a korábban egészségesnek tünő szervezetben felszínre hozhatják az addig rejtett ritmuszavarokat. A terhesség alatt létrejött számos változás többsége a szülést követően elmúlik.

Ha egy terhes nőnél ritmuszavart igazolunk, akkor terápiás lehetőségeink korlátozottak. Részben azért, mert a teratogenitas miatt az antiarrhythmiás gyógyszerek egy része egyáltalán nem vagy csak korlátozottan használható. Ezek a gyógyszerek, proarrhythmiás hatásuk miatt, még a nem terhes populáció számára is kockázatot jelenthetnek, így csak fokozott körültekintéssel adhatók [1]. Másrészt a nonfarmakológiás kezelés is csak bizonyos határok között alkalmazható. A megfelelő kezelés megválasztása speciális ismereteket tesz szükségessé, emiatt csak elektrofiziológiai vizsgálattal foglalkozó centrumban lehet a megválasztandó kezelés formájáról dönteni.

\section{A ritmuszavarok incidenciája várandósság alatt}

A palpitációs panaszok meglehetősen gyakoriak a terhesség időszaka alatt. Míg a terhes nők több mint 50\%-a átélhet hasonló panaszokat, valódi ritmuszavaros epizód 2-3/1000 páciens esetén fordul elő [2].

A nemi különbségek szerepe is jól ismert a ritmuszavarok előfordulásakor. Az AV nodalis reentry tachycardia (AVNRT) incidenciája a nők körében kétszeres a férfia- kéhoz képest, és a gyógyszer indukálta torsade de pointes, valamint a hosszú QT-szindróma is gyakoribb. Ebben a különbségben a nemi hormonok bizonyítottan szerepet játszanak, mivel ez a nóknél tapasztalt magasabb esetszám csak a pubertas után érvényes [3, 4].

\section{A terhességi arrhythmiák kialakulásának mechanizmusai}

A terhesség proarrhythmiás hatású állapot. Az ösztrogén és a $\beta$-humán koriongonadotropin magasabb szintje hatást gyakorol a szív ioncsatornáinak expressziójára. A terhesség során a hemodinamikai változások is jelentősek: nő a keringő vérvolumen, és nagyobb a perctérfogat is. Ez magasabb végdiastolés térfogathoz és pitvari falfeszüléshez vezet [5]. Egy nagyobbra tágult szív könnyebben fenntartja a reentry köröket, és köztudott az is, hogy a mechanikai feszülés is erősen arrhythmogen. A terhesség ezenkívül szimpatikustónus-fokozódással is jár. Magasabb a plazma katecholaminkoncentrációja és az adrenerg receptorok érzékenysége [6].

Mindezek ellenére igen valószínútlen, hogy maga a terhesség generál új arrhythmiaszubsztrátot, sokkal inkább a fent felsorolt tényezők aktiválnak egy már meglévőt. A terhesség a ritmuszavarok triggereit is fokozza, például gyakoriak az ectopiás ütések, melyek a legtöbb ritmuszavar elindítói. Fontos tisztázni, hogy a ritmuszavar strukturális rendellenességgel bíró vagy felépítésében normális szívben jön létre.

A ritmuszavarok veszélyesek mind az anyára, mind a magzatra nézve. Hemodinamikai instabilitást és életveszélyes keringészavarokat okozhatnak. Ezzel egy időben a fetalis keringés is zavart szenvedhet, ami magzatkárosodáshoz vezet.

\section{Diagnosztika}

\section{Nyugalmi EKG}

A megfelelő minőségú, 12 elvezetéses EKG (elektrokardiogram) készítésének jelentőségét nem lehet eléggé hangsúlyozni a ritmuszavarok diagnosztizálásában. Normálesetben is láthatók bizonyos változások terhes nók EKG-ján: magasabb az alapfrekvencia, és rövidebb lehet a PR-távolság. Hosszabb a QTc-idő (átlagosan: 430,30 ms vs. 403,80 ms, terhes vs. nem terhes), ami alacsonyabb szívfrekvenciánál még kifejezettebb [7]. III-as elvezetésben megjelenhet q-hullám és negatív T. A QRStengely balra tolódása is megfigyelhető. Minden, ettől eltérő változás kórosnak tekintendő.

Az első ábrán felsorolt változások megfigyelhetők terhes nők nyugalmi EKG-ján, valamint előfordulhatnak a már ismert arrhythmiákhoz köthető elváltozások (például delta-hullám WPW-ben) [8] (1. ábra). 
Szívfrekvencia nő

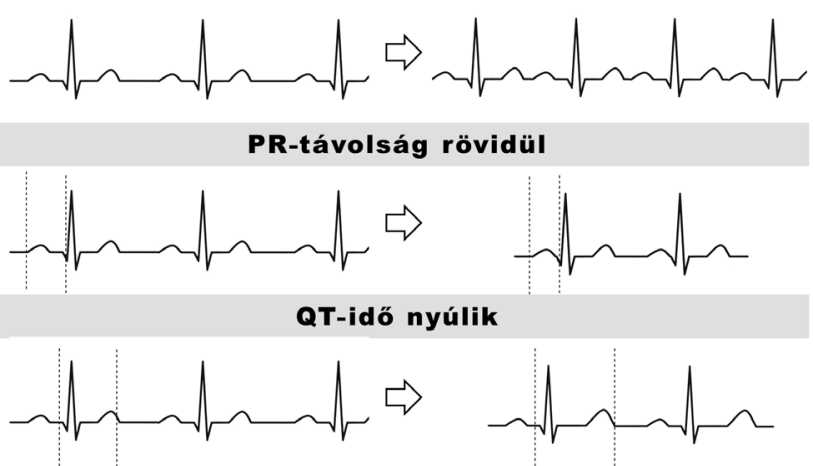

III-ban q-hullám és negatív T

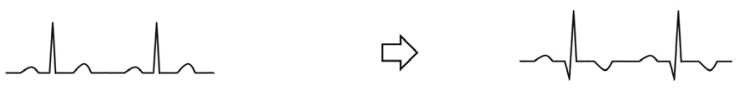

QRS-tengely balra tolódik

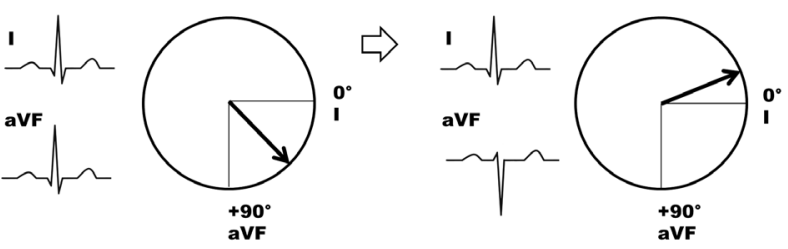

1. ábra

$$
\mid \begin{aligned}
& \text { A várandósság során kialakuló normális EKG-változások } \\
& \text { EKG = elektrokardiogram }
\end{aligned}
$$

\section{Holter}

Az esetek nagy részében sajnos meglehetősen nehéz EKG-val rögzíteni a paroxysmalis tachycardiákat, mivel megjelenésük kiszámíthatatlan. Amennyiben a ritmuszavar napi rendszerességgel vagy naponta többször is je- lentkezik, jó eséllyel regisztrálhatjuk 24 vagy 72 órás Holter-vizsgálattal. Ezenkívül már számos helyen elérhetők azok a kisméretú, hordozható eszközök, amelyekkel a páciens saját maga tud EKG-t regisztrálni (például WIWE).

\section{Szinultrahang (ECHO)}

Fontos vizsgálati eszköz a terhesség során igazolt ritmuszavarban szenvedő betegek kivizsgálásához. Fontossága, hogy meghatározható vele: a ritmuszavart strukturális eltérés okozza-e vagy sem.

\section{Elektrofiziológiai vizsgálat}

Amíg a ritmuszavar gyógyszerekkel biztonságosan kezelhető, és a terhesség kihordható, az ajánlások nem javasolják az invazív vizsgálatokat [9].

\section{A ritmuszavarok kezelési lehetőségei várandósság alatt}

\section{Antiarrhythmiás gyógyszerek}

Terheseken végzett, nagy betegszámú, randomizált vizsgálatok híján kevés adattal rendelkezünk a gyógyszeres lehetőségekről. Az antiarrhythmiás gyógyszereket az FDA (U.S. Food and Drug Administration) szerint soroljuk különböző veszélyességi kategóriákba [9]. A jelenleg használatban lévő készítmények többsége az ún. B vagy $\mathrm{C}$ kategóriába tartozik (1. táblázat). Az FDA irányelvei alapján készült táblázat pedig a leggyakrabban használt antiarrhythmiás gyógyszereket tartalmazza, és azok használhatóságát terhesség, illetve anyatejes táplálás során (2. táblázat).

\section{1. táblázat |Az FDA kategóriabesorolása az antiarrhythmiás gyógyszerek biztonságosságáról várandósság alatt}

\begin{tabular}{|c|c|}
\hline Kategória & Leírás \\
\hline $\begin{array}{l}\text { A - Kontrollált vizsgálatok } \\
\quad \text { igazolták, hogy nincs kockázat }\end{array}$ & $\begin{array}{l}\text { Megfelelő és jól kontrollált vizsgálatok alapján nem igazolható a magzat veszélyeztetettsége az első } \\
\text { trimeszterben (és nincs bizonyíték a kockázatra a későbbi trimeszterekben sem). }\end{array}$ \\
\hline B - Nincs bizonyíték kockázatra & $\begin{array}{l}\text { Állatkísérletes reprodukciós vizsgálatok alapján nem igazolható a magzat veszélyeztetettsége, és nem } \\
\text { állnak rendelkezésre olyan megfelelő, jól kontrollált vizsgálatok, amelyek várandós nők bevonásával } \\
\text { zajlottak volna. }\end{array}$ \\
\hline C - A veszély nem zárható ki & $\begin{array}{l}\text { Állatkísérletes reprodukciós vizsgálatok a magzatot veszélyeztető mellékhatásokat jeleztek, és nem állnak } \\
\text { rendelkezésre megfelelő, jól kontrollált humánvizsgálatok. A potenciális előnyök - a kockázatok ellenére } \\
\text { is - a terhesség alatti gyógyszeres kezelés mellett szólnak. }\end{array}$ \\
\hline D - Kockázatot igazoltak & $\begin{array}{l}\text { Kísérletes vagy klinikai tapasztalatok, illetve humánvizsgálatok alapján pozitív bizonyítékok (nem kívánt } \\
\text { reakciók) jelzik a magzati kockázatot, de a potenciális előnyök a kockázatok ellenére is a gyógyszeres } \\
\text { kezelés mellett szólnak. }\end{array}$ \\
\hline X - Terhességben kontraindikált & $\begin{array}{l}\text { Állatkísérletes vagy humánkutatások magzati rendellenességeket jeleztek, és/vagy kísérletes és klinikai } \\
\text { tapasztalatok, illetve humánvizsgálatok alapján pozitív bizonyítékok (nem kívánt reakciók) jelzik a } \\
\text { magzati kockázatot, és a terhesség alatti gyógyszeres kezelés kockázatai egyértelmúen meghaladják az } \\
\text { abból adódó potenciális elónyöket. }\end{array}$ \\
\hline
\end{tabular}

FDA = az Amerikai Egyesült Államok Élelmiszer-biztonsági és Gyógyszerészeti Hivatala 
2. táblázat |Antiarrhythmiás gyógyszerek a várandósság és az anyatejes táplálás időszaka alatt

\begin{tabular}{|c|c|c|c|c|}
\hline Hatóanyag & FDA-kategória & Biztonságosság várandósság alatt & Nem kívánt hatás & Az anyatejes táplálás időszaka \\
\hline Adenozin & $\mathrm{C}$ & $\begin{array}{l}\text { Biztonságosan adható terhesség- } \\
\text { ben, a magzati ritmusra nincs } \\
\text { detektálható hatása }\end{array}$ & $\begin{array}{l}\text { Kisebb dózis is elegendő } \\
\text { lehet, mivel terhesekben } \\
\text { alacsonyabb az adenozin- } \\
\text { deamináz szintje }\end{array}$ & $\begin{array}{l}\text { A rövid felezési idő miatt } \\
\text { biztonságos }\end{array}$ \\
\hline \multicolumn{5}{|c|}{ Béta-blokkolók } \\
\hline Atenolol & $\mathrm{D}$ & Kontraindikált & Magzati retardáció & Körültekintéssel használható \\
\hline Metoprolol & $\mathrm{C}$ & & $\begin{array}{l}\text { Bradycardia, növekedési } \\
\text { retardáció, apnoe }\end{array}$ & Biztonságos \\
\hline Bizoprolol & $\mathrm{C}$ & & Placenta-hypoperfusio & $\begin{array}{l}\text { Nem javasolt; állatkísérletek } \\
\text { során anyatejben kimutatták }\end{array}$ \\
\hline Propranolol & $\mathrm{C}$ & & $\begin{array}{l}\text { Bradycardia, növekedési } \\
\text { retardáció, apnoe }\end{array}$ & Biztonságos \\
\hline Szotalol & B & Biztonságos & $\begin{array}{l}\text { Bradycardia, hypotensio, } \\
\text { méhen belüli növekedés- } \\
\text { visszamaradás }\end{array}$ & $\begin{array}{l}\text { Adható, de utánkövetés } \\
\text { javasolt; anyatejben } \\
\text { kimutatható }\end{array}$ \\
\hline \multicolumn{5}{|c|}{ Kalciumcsatorna-blokkolók } \\
\hline Diltiazem & $\mathrm{C}$ & Túl kevés adat áll rendelkezésre & $\begin{array}{l}\text { Anyai hypotensio, magzati } \\
\text { bradycardia, növekedési } \\
\text { retardáció, magzati halál }\end{array}$ & Nincs adat \\
\hline Verapamil & $\mathrm{C}$ & $\begin{array}{l}\text { Biztonságos, elsóként választandó } \\
\text { IV. osztályba tartozó gyógyszer } \\
\text { (praeeclampsiában is használatos) }\end{array}$ & $\begin{array}{l}\text { Anyai hypotensio, magzati } \\
\text { bradycardia }\end{array}$ & Adható \\
\hline Digoxin & $\mathrm{C}$ & Nem teratogén & Alacsony születési súly & Adható \\
\hline Amiodaron & $\mathrm{D}$ & $\begin{array}{l}\text { Csak sürgósségi esetben, az anyára } \\
\text { nézve halálos ritmuszavar } \\
\text { megszüntetésére }\end{array}$ & $\begin{array}{l}\text { Teratogén! Magzati } \\
\text { hipothyreosis, növekedési } \\
\text { retardáció }\end{array}$ & Kerülendő \\
\hline
\end{tabular}

FDA = az Amerikai Egyesült Államok Élelmiszer-biztonsági és Gyógyszerészeti Hivatala

\section{Katéterablatio}

A katéterablatio IIa, C evidenciaszintú ajánlású az American Heart Association (AHA) és az Európai Kardiológus Társaság (ESC - European Society of Cardiology) jelenlegi irányelvei szerint [10]. A katéteres beavatkozással kapcsolatos fó probléma a katéterek pozicionálásához használatos, képerősítő készülék által kibocsátott röntgensugárzás. Korábban bizonyították, hogy a páciens (hasának) sugárzás elleni védőeszközökkel történő letakarása haszontalan, mivel az anya mellkasa felől érkező szórt sugárzás okozza a fó dózist a magzat számára [11, 12]. Tapasztalt operatőr biztonsággal képes a katéterek pozicionálását és a ritmuszavarok ablatióját végezni röntgensugár használata nélkül, akár terhes páciensek esetén. Ehhez elengedhetetlen a háromdimenziós térképező rendszerek használata. Amennyiben elérhető, az intracardialis ultrahangvizsgálati (ICE) katéter szintén használható a katéterek szívben történő navigációjához, így nagyban hozzájárulhat a beavatkozás sikerességéhez és a biztonság növeléséhez.

$\mathrm{Az}$ anatómiai tájékozódás régóta elengedhetetlen eszköze a röntgenátvilágítás a rádiófrekvenciás ablatiók során. Ennek az eszköznek a vizualizációban nyújtott segítsége mellett fontos megemlíteni az árnyoldalait is.
Szignifikánsan emelkedett számú daganatos megbetegedést mutattak ki az intervenciós labor személyzetének körében az átlagos populációhoz viszonyítva. A tumorok között a leggyakoribb a bal oldali agy-, pajzsmirigydaganat volt [13]. Ezenkívül gyakoribb a cataracta, és rendkívül nagy számúak az ólomköpeny okozta ortopédiai problémák. Egyre inkább elfogadott nézet, hogy a röntgensugárzásnak a betegre és a személyzetre jutó közvetlen vagy közvetett káros hatását a lehető legnagyobb mértékben csökkenteni kell. A sugárzás káros hatásaira terhesek esetében fokozottabb figyelmet kell fordítanunk, ugyanis intrauterin elhalást, növekedési visszamaradottságot, microcephaliát, kognitív deficitet vagy egyéb létfontosságú szerv degeneratív elváltozását okozhatja. Az ALARA (as low as reasonably achievable) elve kimondja, hogy nincs biztonságos sugárdózis, ezért terhes páciensek esetén a röntgenhasználat tilos. Kórházunkban már több éve sikeresen végezzük az ún. zéró fluoroszkópiás ablatiókat, fóként a pitvarfibrilláció, de más ritmuszavarok esetében is. A röntgensugár használatát a jelen cikkben bemutatott beavatkozások esetén is teljesen kiküszöböltük.

Elektrofiziológiai laboratóriumunkban több alkalommal kerültünk olyan helyzetbe, hogy terápiarezisztens ritmuszavar ablatiójára kényszerültünk, terhesség mellett. 

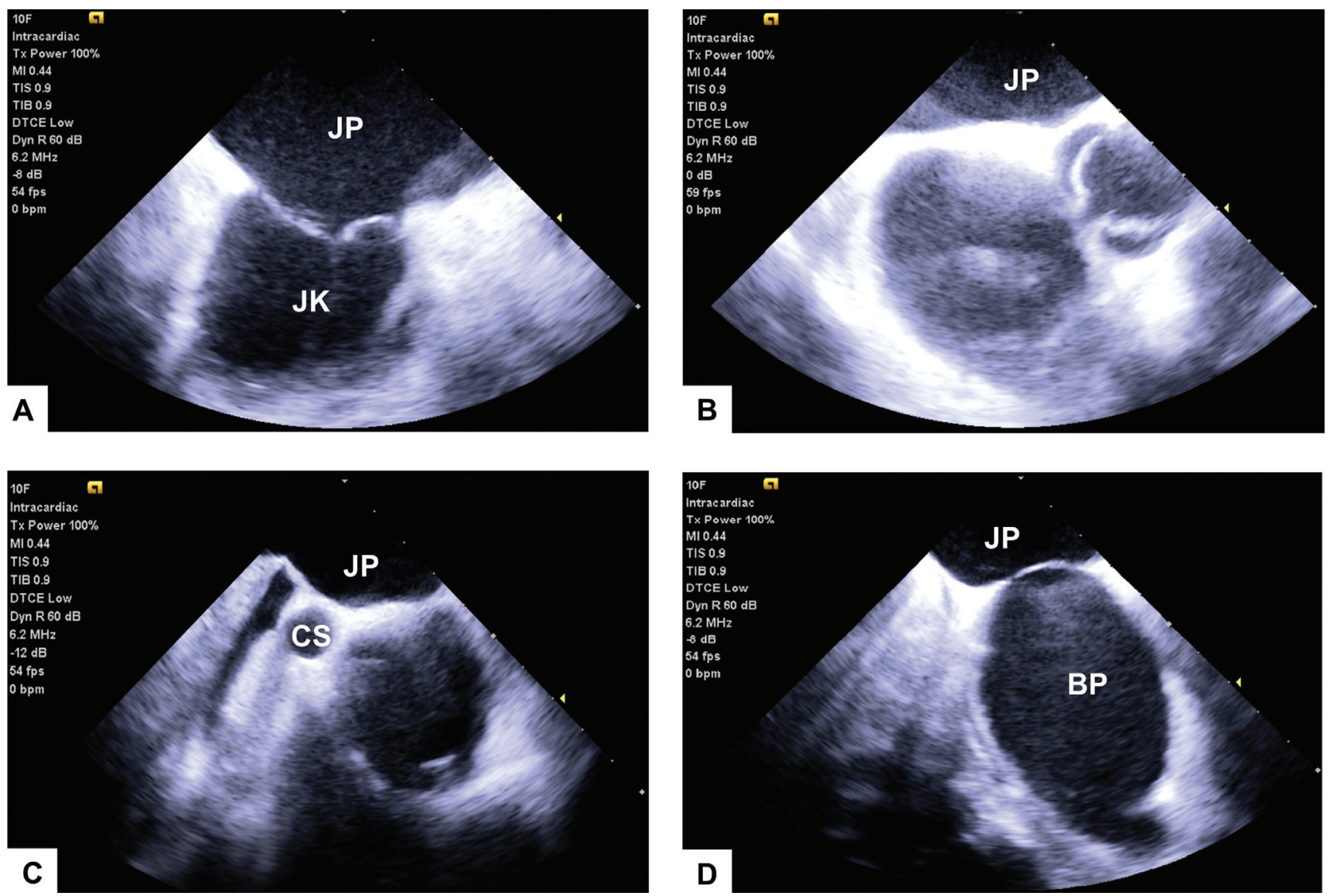

2. ábra

Intracardialis ECHO-képek. Az ICE-katéter a jobb pitvarban található. Segítségével, az óramutató járásának megfelelően körbeforgatva, az A-D ké pek struktúrái hozhatók látótérbe

A) JP = jobb pitvar; JK = jobb kamra, köztük a zárt állapotú tricuspidalis billentyú. B) Nyitott aortabillentyű. C) Sinus coronarius (CS) szájadék. D) Jobb és bal pitvar (BP), valamint a pitvarok közötti septum

$\mathrm{ECHO}=$ echokardiográfia; $\mathrm{ICE}=$ intracardialis ultrahangvizsgálat

Rendelkezésre állnak elektroanatómiai térképezó rendszerek, amelyek segítségével röntgensugár használata nélkül lehet elektrofiziológiai vizsgálatot és katéterablatiót végezni. Az elektroanatómiai térkép pontos másolata a szív belsô felszínének, és a katéterek pontos helyzetét is megadja a szíven belül.

Az ultrahangfejjel ellátott katéterek pedig további képalkotó eszközt jelentenek, és hozzájárulnak a fluoroszkópia mellőzéséhez. Lehetővé teszik a szív különböző struktúráinak valós idejü ábrázolását, a katéterek mozgatását, és korán felfedezhető velük az esetleges thrombus- és buborékképződés. Használatuk mellett bizonyítottan kevesebb a thromboemboliás szövődmények száma, és szignifikánsan rövidebb a sugáridő [14, 15] (2. ábra).

A beavatkozás lehetséges kockázati tényezői a gyors kamrai ingerlés, tachycardiás epizódok, a röntgensugárzás és a háton fektetésből adódó aortocavalis kompreszszió, amelyet oldalt fektetéssel tudtunk volna kivédeni. Szerencsére eseteink kapcsán erre nem volt szükség, ugyanis a szokatlan pozíció megnehezítette volna a ritmuszavarok feltérképezését is. A sikertelenség fó oka ko- rábban közölt esettanulmányokban is a vénás bejutás akadályozottsága volt.

A beavatkozás alatt fontos minimalizálni a gyors kamrai ingerléssel és esetlegesen kiváltott tachycardiával járó epizódokat, mivel ezek a verőtérfogat hirtelen csökkenésével járó események a magzati keringést is veszélyeztetik.

\section{Terápiás ajánlások terhesség alatt az egyes ritmuszavartípusok esetében}

\section{Palpitációs panaszok és extra ütések}

Egy tanulmány szerint a strukturális szívbetegséggel nem rendelkező terhes nők körében igen magas a supraventricularis (57\%) és a kamrai (>50\%) extra ütések előfordulása a nem terhes populációhoz képest $[4,16]$. A panaszokat okozó palpitáció és extra ütésektől szenvedő páciensek esetén kardioszelektív béta-blokkoló kezelés indítható, lehetőség szerint az első trimesztert követően. 


\section{Supraventricularis ritmuszavarok}

\section{„Inappropriate sinus tachycardia”}

Terhesség alatt az „inappropriate sinus tachycardiában” (IST) szenvedő betegek kezelésekor először az empatikus gondozásra, a hatékony kommunikációra, a megfelelő folyadékpótlásra és a rendszeres könnyü testmozgásra kell összpontosítani [17]. Ammenyiben gyógyszeres kezelés szükséges, a béta-blokkolók közül tudunk választani, melyekkel kapcsolatban az ajánlások óvatosságra intenek [18]. Egyelőre a labetololról jelenthető ki, hogy nem ismert káros hatása. Ezzel együtt a bizoprololt, a labetololt, a metoprololt és a propranololt az FDA a C kategóriába sorolta (ez azt jelenti, hogy állatkísérletek során kimutatták magzatkárosító hatásait, és nőkön nem végeztek kontrollált vizsgálatokat), ezért ezeket csak akkor szabad használni, ha feltétlenül indokolt az anya jólléte szempontjából. Az FDA a nem dihidropiridin kalciumcsatorna-blokkolókat is a C kategóriába sorolja [19]. Bár nem kifejezetten besorolt, az FDA leírta, hogy az ivabradin állatkísérletek alapján magzati toxicitást okozhat. Ennek ellenére az ivabradint sikerrel alkalmazták már IST és tachycardia által kiváltott cardiomyopathiában szenvedő terhes betegeknél [20]. Az ESC 2019. évi, supraventricularis tachycardiákra (SVT) vonatkozó irányelvei alapján IST esetében a katéterablatio nem javasolt.

\section{Supraventricularis tachycardiák}

Az arrhythmiás epizód indulásának és megszúnésének, a P-hullám morfológiájának és a P-hullám és a QRSkomplex kapcsolatának, valamint az adenozinra adott válasznak az elemzése általában lehetővé teszi a különböző SVT-mechanizmusok megkülönböztetését. Bármi legyen is a pontos mechanizmus, vagotonicus manőverekkel - például carotis sinus masszázs vagy Valsalva-manőver - megszüntethetők az epizódok, ezért először ezekkel javasolt próbálkozni. Siker esetén a beteg könnyen önállóan kezelheti a ritmuszavarok kiújulását. Ha a vagotonicus manőverek kudarcot vallanak, intravénás bolus adenozin alkalmazható növekvő dózisokban, legfeljebb 18-24 mg-ig. Míg az intravascularis térfogat növekedik terhesség alatt, az adenozin lebontásáért felelős enzim, az adenozin-deamináz szintje csökken, ezért a legtöbb nő 6-12 mg közötti adagokra már reagál. Mivel az adenozin felezési ideje rövid, a szer nem gyakorol hatást a magzatra. Egyúttal reflexesen felgyorsíthatja az arrhythmia kialakulását, ezért azt javasoljuk, hogy tapasztalt személy végezze, az esetleges újraélesztéshez rendelkezésre álló eszközökkel. A verapamil hatékony második vonalbeli szer az SVT-k kezelésében, és legfeljebb 10 mg-os dózisokban alkalmazható a magzati pulzus befolyásolása nélkül. (Bár a magzati distresszt összefüggésbe hozták a verapamil által kiváltott anyai hypotensióval.) Supraventricularis ritmuszavarokon kívül rutinszerúen alkalmazzák praeeclampsia kezelésében is, és a vizsgálatok során nem mutattak ki teratogén hatást [9].
Az ismert WPW-vel rendelkező nőknél a béta-blokkolók a választandó gyógyszerek. Az AV csomó átvezetését rontó szerek, úgymint a digoxin és a kalciumcsatornablokkolók, nem javasoltak, mivel a köteg felé terelik az átvezetést, ami felgyorsíthatja a ritmuszavart [2].

\section{Pitvarfibrilláció és pitvari flutter}

A pitvarfibrilláció és a pitvari flutter terhesség alatt nem gyakori, előfordulásuk a leggyakrabban veleszületett szívbetegséghez, vitiumhoz, valamint anyagcserezavarokhoz, például thyreotoxicosishoz vagy elektrolitzavarokhoz köthető. Előnyös gyógyszerek a béta-blokkolók (szotalol, atenolol) vagy a flekainid. A prokainamid egy másik biztonságos alternatíva, míg az amiodaront csak akut, életet veszélyeztető szituációkban alkalmazhatjuk teratogén hatása miatt [21]. Azokban az esetekben, amikor a sinusritmus helyreállítása helyett a frekvenciakontrollra van szükség, a megfelelő antikoaguláció mellett a béta-blokkolók, a verapamil és a digoxin az elónyben részesített gyógyszerek [22].

Antikoagulánsként szinte csak az alacsony molekulatömegú heparin (LMWH) adása jön szóba. A K-vitaminantagonisták ellenjavalltak, mivel teratogén hatásúak. Warfarin esetleg használható a második és a harmadik trimeszterben [23]. Az új típusú antikoagulánsok (NOAC) biztonságosságáról, azok közül is a dabigatránról, a rivaroxabanról és az intravénás direkt trombininhibitorokról egyelőre kevés adat áll rendelkezdésre [24]. Esetleírások már történtek az intravénás szerek használatáról heparin indukálta thrombocytopenia esetén. Ezen megfontolások miatt a fent felsorolt gyógyszerek használata, az LMWH kivételével, nem javasolt [25].

\section{Kamrai ritmuszavarok}

\section{Idiopathiás kamrai tachycardia}

Az idiopathiás jobb kamrai tachycardia (VT), amely a jobb kamrai kiáramló traktusból származik, az idiopathiás VT leggyakoribb formája terhesség alatt. Gyakorlatilag soha nem gyorsul fel instabil ritmusra, és bigeminia vagy nem tartós VT képében jelentkezik. A QRS-morfológia lehet bal szárblokk mintázatú, alsó tengelyú, amely jól reagál a béta-blokkolókra [26]. Az idiopathiás bal kamrai VT a jobb szárblokk mintájával jóval ritkábban fordul elő, és jól reagál a verapamilra [2].

\section{Monomorf kamrai tachycardia a szerkezetileg rendellenes szívben}

Bármely betegség, amely a kamrai szívizmot érinti, hegesedést, hypertrophiát vagy infiltrációt okozhat, megzavarhatja a szívizom elektromos integritását. Szívfejlődési rendellenesség esetén a kamrai tachycardia előfordulása 4,5-15,9 minden 1000 terhességben. A gyors kamrai ritmus hypotensiót, csökkent szívizomkoszorúér-perfúziót és subendocardialis ischaemiát okoz, olyan instabil állapotot, amely kamrafibrillációvá fajulhat. Strukturális szívbetegség jelenlétében a VT a hirtelen halál jelentős 
kockázatával jár, és sürgősségi kezelést igényel. Hemodinamikai instabilitás esetén azonnali cardioversiót kell végezni. Amennyiben a beteg hemodinamikailag tolerálja a VT-t, a kezelést intravénás lidokain adásával kezdhetjük. Ha a lidokain ineffektív, iv. prokainamid jön szóba. Potenciális magzatkárosító hatása miatt amiodaron adásához akkor nyúlhatunk, ha életet veszélyeztető állapot áll fenn, és más terápiás lehetőségeink kimerültek [2].

\section{A visszatérő $\mathrm{VT}$ megelőzése}

A strukturális szívbetegséghez társuló VT potenciálisan rosszindulatú. A legtöbb, VT-ben szenvedő betegnek defibrillátorbeültetésen kell átesnie. Terhesség esetén ez a beavatkozás minimális sugárdózissal vagy röntgen nélkül (például ultrahangos képalkotással) elvégezhető. Antiarrhythmiás gyógyszeres terápia alkalmazható idiopathiás VT-ben szenvedő betegeknél strukturális szívbetegség hiányában. A béta-blokkolók az elsô vonalbeli terápia. Ha a béta-blokkolók hatástalanok, vagy a betegek nem tolerálják a kalciumcsatorna-blokkolókat (idiopathiás bal kamrai VT esetén), akkor fontolóra lehet venni a szotalolt, vagy alternatíva lehet a mexiletin, illetve a flekainid [27]. Az idiopathiás VT katéterablatióval gyógyítható, nagyon magas sikeraránnyal (>99,0\%). A farmakológiai terápia megválasztása strukturálisan rendellenes szív esetén összetettebb, mivel néhány antiarrhythmiás gyógyszer súlyosbíthatja a helyzetet (például az I/C osztályú szerek növelik a mortalitást strukturális szívbetegségben nem terhesek esetén). Ez esetben is elsősorban a béta-blokkolókhoz tudunk nyúlni.

\section{A centrumunkban végzett katéterablatiók közül két példa}

Két eset bemutatásán keresztül prezentáljuk a supraventricularis arrhythmiák sikeres katéterablatiós megoldását a CARTO térképező rendszer segítségével, és részletezzük az általunk alkalmazott nonfluoroszkópiás módszer használatát.

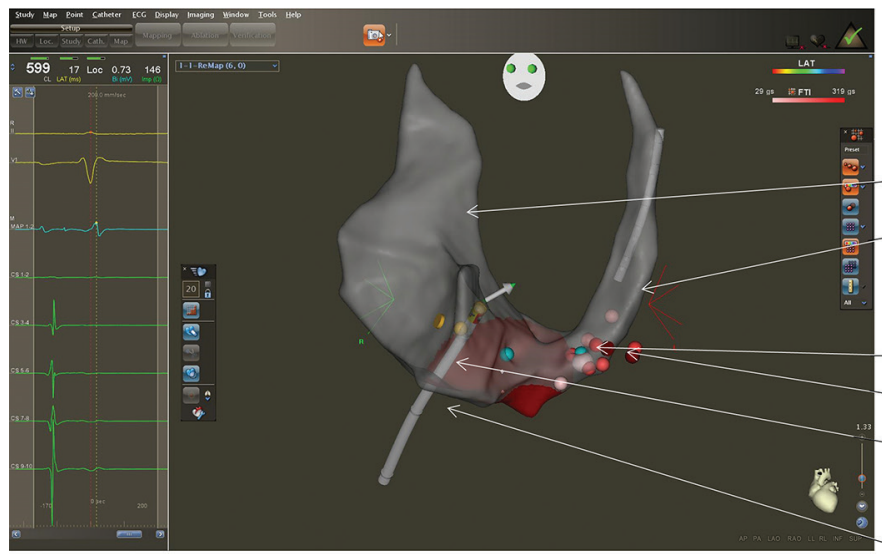

\section{Elsö eset - AVNRT-ablatio röntgenhasználat nélkül}

AVNRT miatt végeztük a 23. gestatiós hetében járó várandós nő reablatióját. Második terhességét töltötte, amikor ismételten jelentkeztek ritmuszavarai. Korábbi terhessége után AV csomó lassú pálya és posteroseptalis járulékos köteget abláltunk, ezt követően tünet- és panaszmenetes volt.

Újbóli várandóssága alatt visszatértek palpitációs panaszai. Több alkalommal sürgősségi osztályos felvétel is indokolttá vált, a nem szûnő keskeny QRS-tachycardiás epizódok miatt. Intravénás adenozin, majd béta-blokkoló adása sem állította meg ritmuszavarát. Ideiglenes pacemakerelektróda bevezetése és a ritmuszavar elektromos felülvezérlése oldotta meg végül panaszait. Erre az invazív beavatkozásra többször sor került a 23. gesztációs hétig. Számba vettük a tüneteket okozó ritmuszavarát, a ritmuszavar refrakteritását a gyógyszeres kezelésre és a röntgensugárzásnak a magzat fejlődésére gyakorolt hatását. Végül az anyára és magzatára nézve is veszélyeket jelentő ritmuszavar katéterablatiós eliminációja mellett döntöttünk, a fluoroszkópia használatát mellőzve. A katétereket intracardialis ultrahangvizsgálat segítségével vezettük fel. A jobb pitvarban elektroanatómiai térképet vettünk fel, majd elektrofiziológiai vizsgálatot végeztünk. A vizsgálat során rekurrens AVNRT-t igazoltunk. A lassú pálya helyének megfelelően 3 rádiófrekvenciás applikációt adtunk le. 30 perc várakozás után ritmuszavart nem tudtunk kiváltani. Sem az anya, sem a magzat tekintetében nem észleltünk szövődményt. A béta-blokkoló kezelést felfüggesztettük. 39 hetesen egészséges újszülöttet hozott világra (3. ábra).

\section{Második eset - anteroseptalis köteg zéró fluoroszkópiás ablatiója}

Az ismert WPW-szindrómás, 24 hetes gravid nőbeteget a harmadik terhessége során fellépő, gyógyszerrel uralhatatlan PSVT-epizódok miatt kezeltük osztályunkon.

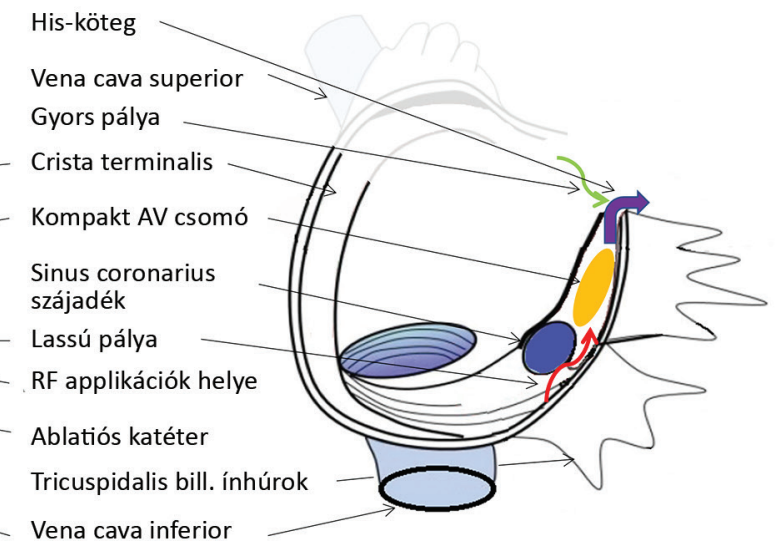

3. ábra Bal oldalon: CARTO elektroanatómiai térkép az ablatio helyéról, a jobb pitvarban. A jobb oldali ábra a térkép sematikus magyarázata $\mathrm{AV}=$ atrioventricularis; $\mathrm{RF}=$ rádiófrekvenciás 
2011-ben, az előző terhessége alatt számos paroxysmalis ritmuszavaros epizódot élt át, amelyek szülés után és a következő várandósságáig nem fordultak elő. A beavatkozásokhoz a CARTO 3 elektroanatómiai térképező rendszert használtuk. A katéterek felvezetéséhez és a jobb pitvarban történő tájékozódáshoz, valamint a lehetséges szövődmények korai észlelése érdekében intracardialis ECHO-t alkalmaztunk. A sinus coronarius és a jobb kamrai elektródákat szintén az ICE segítségével pozicionáltuk. Ezt követően a Thermocool SmartTouch ablatiós katéter segítségével jobb pitvari elektroanatómiai térképet készítettünk.

Többszörös ablatiókat végeztünk; ablatio során a kötegvezetés megszúnt, azonban több alkalommal is újraindult. Ablatio során egy alkalommal 1 perces teljes AV blokk, majd 200 ms-os PQ-idővel sinusritmus tért viszsza. Az ablatiókat követően a kötegvezetés teljesen megszűnt, és 20 perc várakozást követően sem tért vissza. A beavatkozás szövődményeként megnyúlt AV átvezetés maradt hátra, megtartott funkciójú AV vezetés mellett. Pacemakerbeültetést a későbbiekben nem igényelt. A hátralévő 26 hétben terhessége problémamentesen zajlott.

\section{Következtetések}

A ritmuszavarok korai felismerése és kezelése fontos mind a szülész-nőgyógyász, mind a gondozó kardiológus részéról. A legtöbb esetben már a terhességet megelőzően diagnosztizálható az egyén hajlama az adott ritmuszavar kialakulására. Alarmírozó adat, hogy 29\%-ban rosszabbodás várható a ritmuszavaros tünetekben, sőt a későbbi terhességek során egyre hevesebben jelentkezhetnek. Ezenfelül megfontolandó az igazolt ritmuszavar katéterablatióját még a gyermekvállalás tervezése előtt elvégezni, különösen pitvari tachycardia, WPW-szindróma és paroxysmalis junkcionális reciprok tachycardia (PJRT) esetén. A katéterablatio manapság valós kezelési alternatívát jelent, már a terhesség ideje alatt is. Az általánosan elterjedt elektroanatómiai térképező rendszerek, valamint az intracardialis ultrahangkészülékek segítségével mára - a korábban csak röntgensugárzás használatával végezhető - invazív elektrofiziológiai vizsgálatok és a katéterablatio lényegesen kisebb megterhelést jelent mind az anya, mind a magzat számára. Tekintettel a terhesség okozta hormonális, anatómiai, hemodinamikai és elektrofiziológiai változásokra, a beavatkozás fokozott körültekintéssel végzendő, gyakorlott centrumban és tapasztalt operatőr által. Természetesen nem cél az, hogy a ritmuszavarokat a terhesség alatt oldjuk meg, az általunk leírt módszer csak egy lehetőséget jelent a terápiarefrakter ritmuszavarok oki terápiájára. A valós megoldás az lenne, hogy fiatal, fogamzóképes nőkön minél nagyobb arányban legyenek felderítve a potenciálisan invazívan kezelhető ritmuszavarok, és ezeket még a tervezett gyer- mekvállalás előtt gyógyítsuk meg. Ennek a kezdeményezésnek a kivitelezése nőgyógyászok, háziorvosok, valamint kardiológusok közös feladata.

Anyagi támogatás: A közlemény megírása, illetve a kapcsolódó kutatómunka anyagi támogatásban nem részesült.

Szerzôi munkamegosztás: T. T.: Az elektrofiziológiai beavatkozások elvégzése. R. Á.: Irodalomkutatás, az ábrák és a táblázatok elkészítése. R. Á., T. T.: A kézirat megírása. T. T., L. G.: Szakértői feladatok ellátása, stilisztikai munkák. T. T., R. Á., N. B., Á. F.: A betegek utánkövetése.

Érdekeltségek: A szerzőknek nincsenek érdekeltségeik.

\section{Irodalom}

[1] Fazekas T, Smeets JL, Wellens HJ. Arrhythmogenic actions of antiarrhythmic agents. An up-to-date clinical view on proarrhythmias. $[\mathrm{Az}$ antiaritmiás gyógyszerek aritmogén hatása. A proaritmiák korszerű klinikai szemlélete.] Orv Hetil. 1991; 132: 2243-2248. [Hungarian]

[2] Adamson DL, Nelson-Piercy C. Managing palpitations and arrhythmias during pregnancy. Heart 2007; 93: 1630-1636.

[3] Wolbrette D, Patel H. Arrhythmias and women. Curr Opin Cardiol. 1999; 14: 36-43.

[4] Wolbrette D, Naccarelli G, Curtis A, et al. Gender differences in arrhythmias. Clin Cardiol. 2002; 25: 49-56.

[5] Hankovszky P. Arrhythmias during pregnancy. [Szívritmuszavarok a terhesség során.] Szegedi Tudományegyetem, Anesztezi ológiai és Intenzv Terápiás Intézet, Szeged, 2012. [Hungarian]

[6] Greenwood JP, Scott EM, Stoker JB, et al. Sympathetic neural mechanisms in normal and hypertensive pregnancy in humans. Circulation 2001; 104: 2200-2204.

[7] Zamani M, Esmailian M, Yoosefian Z. QT interval in pregnant and non-pregnant women. J Emerg. 2014; 2: 22-25.

[8] Wenger NK, Hurst JW, Strozier VN. Electrocardiographic changes in pregnancy. Am J Cardiol. 1964; 13: 774-778.

[9] Merino JL, Perez-Silva A. Tachyarrhythmias and pregnancy. E-J Cardiol Pract. 2011; 9: $\mathrm{N}^{\circ} 31$

[10] Regitz-Zagrosek V, Roos-Hesselink JW, Bauersachs J, et al. 2018 ESC guidelines for the management of cardiovascular diseases during pregnancy. Eur Heart J. 2018; 39: 3165-3241.

[11] Damilakis J, Theocharopoulos N, Perisinakis K, et al. Conceptus radiation dose and risk from cardiac catheter ablation procedures. Circulation 2001; 104: 893-897.

[12] Lindsay BD, Eichling JO, Ambos HD, et al. Radiation exposure to patients and medical personnel during radiofrequency catheter ablation for supraventricular tachycardia. Am J Cardiol. 1992; 70: 218-223

[13] Andreassi MG, Piccaluga E, Guagliumi G, et al. Occupational health risks in cardiac catheterization laboratory workers. Circ Cardiovasc Interv. 2016; 9: e003273.

[14] Ren JF, Marchlinski FE, Callans DJ. Left atrial thrombus associated with ablation for atrial fibrillation: identification with intracardiac echocardiography. J Am Coll Cardiol. 2004; 43: 18611867.

[15] Mah DY, Miyake CY, Sherwin ED, et al. The use of an integrated electroanatomic mapping system and intracardiac echocardiography to reduce radiation exposure in children and young adults 
undergoing ablation of supraventricular tachycardia. Europace 2014; 16: 277-283.

[16] Shotan A, Ostrzega E, Mehra A, et al. Incidence of arrhythmias in normal pregnancy and relation to palpitations, dizziness, and syncope. Am J Cardiol. 1997; 79: 1061-1064.

[17] Belham M, Patient C, Pickett J. Inappropriate sinus tachycardia in pregnancy: a benign phenomena? BMJ Case Rep. 2017; 2017: bcr2016217026.

[18] Enriquez AD, Economy KE, Tedrow UB. Contemporary management of arrhythmias during pregnancy. Circ Arrhythm Electrophysiol. 2014; 7: 961-967.

[19] Regitz-Zagrosek V, Blomstrom Lundqvist C, Borghi C, et al. ESC guidelines on the management of cardiovascular diseases during pregnancy: the Task Force on the Management of Cardiovascular Diseases during Pregnancy of the European Society of Cardiology (ESC). Eur Heart J. 2011; 32: 3147-3197.

[20] Sağ S, Çoşkun H, Baran İ, et al. Inappropriate sinus tachycardiainduced cardiomyopathy during pregnancy and successful treatment with ivabradine. Anatol J Cardiol. 2016; 16: 212-213.

[21] Widerhorn J, Bhandari AK, Bughi S, et al. Fetal and neonatal adverse effects profile of amiodarone treatment during pregnancy. Am Heart J. 1991; 122: 1162-1166.
[22] Kron J, Conti JB. Arrhythmias in the pregnant patient: current concepts in evaluation and management. J Interv Card Electrophysiol. 2007; 19: 95-107.

[23] Fuster V, Rydén LE, Cannom DS, et al. ACC/AHA/ESC 2006 guidelines for the management of patients with atrial fibrillation. Europace 2006; 8: 651-745. [Erratum: Europace 2007; 9: 856.]

[24] Beyer-Westendorf J, Tittl L, Bistervels I, et al. Safety of direct oral anticoagulant exposure during pregnancy: a retrospective cohort study. Lancet Haematol. 2020; 7: e884-e891.

[25] DiCarlo-Meacham A, Dahlke J. Atrial fibrillation in pregnancy. Obstet Gynecol. 2011; 117: 489-492.

[26] Brodsky M, Doria R, Allen B, et al. New-onset ventricular tachycardia during pregnancy. Am Heart J. 1992; 123: 933-941.

[27] Cordina R, McGuire MA. Maternal cardiac arrhythmias during pregnancy and lactation. Obstet Med. 2010; 3: 8-16.

(Riba Ádám dr., Zalaegerszeg, Zrínyi M. út 1., 8900 e-mail: adam8804@gmail.com)

\author{
Állásajánlat \\ A balatonfüredi „DRC” Gyógyszervizsgáló Központ \\ szakorvos kollégát keres \\ heti 1 vagy 2 napon klinikai gyógyszervizsgálatok végzéséhez. \\ Angol nyelvtudás szükséges. \\ Ráépített kliniko-farmakológiai szakvizsga, \\ vagy ilyen munkában szerzett gyakorlat előnyt jelent. \\ Jelentkezés: +36 87481 616, drc@drc.hu. \\ Cím: 8230 Balatonfüred, Ady E. u. 12/B.
}

A cikk a Creative Commons Attribution 4.0 International License (https://creativecommons.org/licenses/by/4.0/) feltételei szerint publikált Open Access közlemény melynek szellemében a cikk bármilyen médiumban szabadon felhasználható, megosztható és újraközölhetö, feltéve, hogy az eredeti szerzỏ és a közlés helye, illetve a CC License linkje és az esetlegesen végrehajtott módosítások feltüntetésre kerülnek. (SID_1) 